health, as well as for general workers in the interests covered by its contents. There is a mass of information about present-day affairs not available elsewhere as a whole within one book. In such a compendium the accuracy of figures may vary from country to country. The figures given could not be obtained elsewhere, except by laborious inquiry or search from a number, a very large number, of sources. To provide such a mass of information within a reasonable space, a very elaborate system of notation is used, this in itself requiring to be used when gleaning the data provided. There is an elaborate and useful index. The whole of the book is printed in three languages-English, French and Spanish.

\section{Fertilization in Farm Animals}

J. L. Hancock, of the Animal Breeding Organization, Edinburgh, has reviewed fertilization in farm animals (Animal Breeding Abstracts, 30, 285; 1962), and dealt with some 200 references of recent years. The text covers "Physiological Aspects of Fertilization" (duration of cestrus, time of ovulation, site of fertilization, time taken for spermatozoa to reach site of fertilization, numbers of spermatozoa at site of fertilization, functional life-span of spermatozoa in the female tract, functional life-span of the ovum, penetration of ova, morphological changes preceding and following fertilization, changes in unfertilized ova, criteria of fertilization, anomalies of fertilization), "Failure of Fertilization" (failure of sperm transport, defective gametes) and "Fertilization in Hormone-treated Females" (fertilization in vitro after ovum transfer, selective fertilization). Hancock emphasizes that basic information on the physiology of fertilization in animals is derived largely from studies of small laboratory animals.

\section{Courses in Research and Development}

The Comparative Administration Trust is organizing practical courses on "Administration and Management of Research and Development" in collaboration with Brooklands Technical College, Weybridge (January 14-February 8), Gonville and Caius College, Cambridge (July 14August 9), Queen's College, Oxford (September 1-28), and Sundridge Park Management Centre, Bromley (November 10-December 7). The courses will be open to those with science or engineering degrees or equivalent qualifications, and are aimed at improving the practical effectiveness of those engaged in administration and management of technical work in industry, in industrial research associations or publicly sponsored research establishments. Forms of application and further information can be obtained from the Comparative Administration Trust, $30 \mathrm{St}$. George Street, Hanover Square, London, W.1.

\section{Nato Advanced Study Institute on Palæoclimates}

AN Advanced Study Institute on Palæoclimates will be held under the auspices of the Northern Atlantic Treaty Organization's Science Office at King's College, Newcastle upon Tyne, during January 7-12. The programme has been divided into eleven sessions dealing with: the palæoclimatic significance of coal; Cretaceous and Tertiary palæobotany; palæontology and palæoecology; palæontology; glaciation; Eo-Cambrian glaciation and Devonian climate; deserts and palæowind aspects; evaporites; Permian climate; soils; meteorological aspects. The director of the Institute is Prof. S. K. Runcorn, head of the Physics Department, King's College. Further information can be obtained from the organizing secretary, Dr. A. E. M. Nairn, Nato Advanced Study Institute on Palæoclimates, King's College, Newcastle upon Tyne.

\section{The British Society of Acoustic Technology}

UNDER the directions of committee of representatives from universities, local government, industry and the
Royal College of Advanced Technology at Salford, and headed by Dr. L. H. A. Pilkington, of Messrs. Pilkingtno Bros., St. Helens, a Society of Acoustic Technology is to be formed. A programme has been prepared which includes both lectures and visits; topics which the Society will consider in the first half-session (beginning in January) include airport noise, psychological problems caused by excessive or particularly penetrating noise, measurement of noise-levels and the design of lightweight partitions intended to reduce noise. The inaugural meeting of the Society will be held on January 17 at the Royal College of Advanced Technology, Salford, when Prof. E. J. Richards, of the University of Southampton, will give an address on "Future Problems in Noise Abatement". The joint honorary secretaries of the Society are Dr. P. Lord, of the Department of Pure and Applied Physics, Royal College of Advanced Technology, Salford, and Dr. H. D. Parbrook, of the Sub-department of Acoustics, University of Liverpool. Further information concerning the inaugural moeting can be obtained from Dr. Lord.

\section{Announcements}

Sir John WoLfEnden, vice-chancellor of the University of Reading, has been appointed to succeed Sir Keith Murray as chairman of the University Grants Committee. Sir Keith Murray will relinquish the post on September 30 , by which time he will have served for ten years.

Dr. R. Franklyn Morris, of the Federal Department of Forestry, Fredericton, New Brunswick, has been awarded the first Gold Medal of the Entomological Society of Canada for his work in the field of insect population dynamics. Dr. Morris's work has provided a scientific basis for attempting the control of budworm.

M. S. Moss has been appointed to take charge of the Animal Health Trust's forensic laboratory at the Equine Research Station, Newmarket. Mr. Moss has been a member of the Metropolitan Police Laboratory, New Scotland Yard, where he has investigated the techniques of extraction and identification of drugs. The forensic laboratory at the Equine Research Station has been established to implement some of the recommendations contained in the report of the committee, under the chairmanship of the Duke of Norfolk, which inquired into the question of 'doping' of racehorses.

THe British Association for Commercial and Industrial Education is organizing a special conference to consider the White Paper (Cmnd. 1892) Industrial Training: Government Proposals, which will be held at the Grand Council Chamber, Federation of British Industries, 21 Tothill Street, London, S.W.1, on January 15. Further information can be obtained from the Conference Secretary, BACIE, 26a Buckingham Palace Road, London. S.W.1.

A menting of the Systematics Association on "The Place of Taxonomy in the Teaching of Biology" will be held in the Department of Botany, University of Birming. ham, on January 26. Further information can be obtained from the Honorary Botanical Secretary, the Systematics Association, c/o British Museum (Natural History), Cromwell Road, London, S.W.7.

"The Role of Chemical Engineering in the Space Age" is the title of a lecture to be given by Prof. Ju Chin Chu, professor of chemical engineering at the Polytechnic Institute of Brooklyn, at the Geological Society, Burlington House, London, W.1, on January 28. The lecture is being organized by the Institute of Chemical Engineers, and further information can be obtained from the General Secretary of the Institute, 16 Belgrave Square, London, S.W.1. 